\title{
TRANSFER AND REFERRAL OF A PRACTICING NURSE TO TASKS RELATED TO PREVENTING, COUNTERACTING, AND COMBATING THE COVID-19 EPIDEMIC
}

Dorota Karkowska ${ }^{\mathrm{A}, \mathrm{B}, \mathrm{C}, \mathrm{D}, \mathrm{E}, \mathrm{F}}$

Institute of Nursing and Midwifery, Faculty of Health Sciences, Jagiellonian University Medical College, Krakow, Poland

Authors' contribution:

A. Study design/planning • B. Data collection/entry $\bullet$ C. Data analysis/statistics $\bullet$ D. Data interpretation $\bullet$ E. Preparation of manuscript $\bullet$ F. Literature analysis/search $\bullet$ G. Funds collection

\author{
Address for correspondence: \\ Prof. Dorota Karkowska \\ Institute of Nursing and Midwifery \\ Faculty of Health Sciences \\ Jagiellonian University Medical College \\ 25 Kopernika St., 31-501 Krakow, Poland \\ e-mail: dorota.karkowska@uj.edu.pl \\ SUBMITTED: 28.05 .2020 \\ ACCEPTED: 21.07 .2020 \\ DOI: https://doi.org/10.5114/ppiel.2020.98765
}

\begin{abstract}
The article was prepared on the basis of an analysis of current legal acts and case law of common courts, in particular the Supreme Court. Based on the analysis, the conclusion is that the possibility of transferring or referring a nurse to work in combating the effects of the COVID-19 epidemic depends on the form of employment and the mode of performed activity. Nurses with an employee status who are transferred to perform tasks other than the ones specified in the employment contract, by way of an employer's official order issued in accordance with Article 42 Paragraph 4 of the Labour Code, are not subject to the exclusion due to the care of a minor child, a chronically ill person, or due to the age of 60 years or more. However, according to the Labour Code, women will be subject to such an exemption during pregnancy or nursing a baby. The possibility of obliging a nurse employed on the basis of a civil law contract to take care of persons with suspected coronavirus infection is decided by the parties by making a declaration of will in the contract. Regardless of the current form of practicing the profession, a nurse may be referred to work in combating an epidemic, including the care of persons with suspected coronavirus infection, through the administrative and legal mode, based on the decision of the voivode or the minister of health.
\end{abstract}

Key words: work, transfer, referral, COVID-19.

\section{INTRODUCTION}

The purpose of this article is to analyse legal conditions for the transfer or referral of a nurse to work in healthcare entities or other organisational units in which there are persons with suspected or confirmed COVID-19 infection. At the same time, it tries to answer the following question: When can an entity that is authorised to transfer or refer nurses to combat the effects of an epidemic do so even against their will?

In order to carry out the tasks resulting from the introduction of the epidemic status in Poland, public healthcare entities are currently making changes in their organisational structure, consisting of transforming multi-profile hospitals into single-name hospitals, i.e. infectious disease hospitals, or transforming some of their organisational units into healthcare units destined only for patients with suspected or confirmed COVID-19 infection [1; hereinafter also referred to as: COVID-19 Act]. In those transformed healthcare entities or organisational units of healthcare entities, the situation of the nursing staff changes radically.
For example: a nurse who has been working in a paediatric ward until that point in time or a nurse working in a nursery are transferred to work in isolation wards in order to take care of people of different ages with either suspected or confirmed COVID-19 infection. In addition, in order to combat the effects of the epidemic, nurses working so far in different places are referred to work in nursing homes.

Generally, there are two different legal regimes contemplating the possibility of referring nurses to carry out tasks other than the ones they had performed previously.

Obligation relations, i.e. as part of previous employment in a healthcare entity, where work is performed on the basis of:

1. An employment agreement, i.e. concluded between an employee and an employer.

2. Civil law agreement, the so-called service contract concluded between:

a) healthcare provider (employing entity) and a nurse practicing the profession as part of an individual/ 
specialist professional practice exclusive to that healthcare entity, so-called self-employment;

b) healthcare provider (employing entity) and a nurse as a natural person not being a sole proprietorship.

Public law regime, i.e. in the administrative law mode, based on the decision of the voivode or the minister of health to refer a nurse to work in combating an epidemic, regardless of the current form of profession practice.

\section{REFERRING A NURSE TO CARRY OUT TASKS OTHER THAN THOSE PROVIDED FOR IN THE EMPLOYMENT CONTRACT}

By way of an official order, i.e. orally the employer has the right to refer the employed nurse to perform tasks others than those specified in the employment contract, provided that a total of four statutory conditions are met: 1) it must be justified by the employer's needs, 2) it does not cause a reduction of employee's remuneration, 3) it corresponds to the employee's qualifications, and 4) the referral to another job may not exceed three months in a calendar year [2]. This means that if the four above-mentioned conditions are met, a nurse or midwife cannot refuse to undertake those tasks even though they had not performed them previously.

\section{The legitimate needs of the employer and the epidemic state arising from the threat of the spread of SARS-CoV-2 infection}

The transfer of a nurse to carry out tasks other than the ones previously performed must be dictated by the "legitimate needs of the employer". The regulations do not specify which employer's needs should be considered justified in this case. Such needs of the employer are usually understood as the needs arising from the need to ensure the implementation of the tasks of the workplace or part of it, the nonperformance of which would expose the employer to harm. There are no requirements to limit the needs of the workplace only to the needs of the organisational unit (cell, facility) of the workplace to which the employee was referred. The needs of the workplace should be understood broadly, and so these are the needs of the workplace as a whole [3].

Due to the epidemic state introduced in Poland, public healthcare entities are obliged to perform tasks related to counteracting COVID-19, in accordance with the provisions of this Act. The extraordinary situation arising from the threat of the spread of SARS-CoV-2 infection and the need to introduce specific organisational solutions in public health care entities is the statutory premise of "justified employ- er's needs" for referring employees to perform tasks other than those carried out before, in accordance with their qualifications and health conditions [4].

The demonstration of a legitimate need in the event of a dispute with the employee is borne by the employer $[5,6]$.

\section{Adequacy of possessed qualifications}

A nurse can be transferred only to carry out such tasks that correspond to their qualifications, and thus may not exceed them, but at the same time their qualifications should find appropriate use in the performed work. The tasks carried out by an employee for a temporary period should be consistent with their qualifications, but not necessarily with those required by the type of work specified in the employment contract [7, 8]. Usually, one workplace and position will not fulfil the scope of the concept of work consistent with the level of qualifications held [9]. A position suitable for the employee's qualifications is one that does not exceed them and in which these qualifications will be applied at least partially.

It should also be taken into consideration that the term 'qualifications', so important for determining the type of work performed by a given nurse at the employer's workplace, should be understood not only as the professional qualifications of the person: their formal education, experience and professional practices [10], and the skills needed, but also the psychophysical characteristics of the employee, their mental predisposition, and their ability to perform specific activities from the point of view of physical and mental health. In accordance with Article 229 Paragraph 1 Item 2 of the Labour Code [11], medical check-up applies to employees transferred to workstations with harmful or onerous conditions. Unfortunately, since the announcement of the epidemic threat or epidemic status the performance of periodic medical examinations is suspended, and at the same time there is currently no obligation to carry out medical examinations in nurses transferred by the employer to another job [12].

However, in my opinion, beyond any doubt, the employer should examine whether the employee may be temporarily referred to perform new obligations given their age and health condition.

\section{Transfer period}

A nurse who has the status of an employee may be transferred to another job for a period not exceeding three months in a calendar year. The employer may exercise this right once (for the next three months) or several times (for periods of up to three months in total). In practice, if all the conditions are met, the employer may transfer the employee in the last three months of one calendar year and again in the first three months of the next calendar year. 


\section{Transfer procedure and means of appeal}

An employer transferring a nurse to another job does not have to give them a transfer notice. An oral official order given to a nurse is sufficient, i.e. for the proper transfer of an employee a written form is not necessary [13], the employer does not have to justify their order, a prior consultation with the trade union organisation representing the employee is not required, and the employer is not obliged to inform the employee about the possibility of appealing to the court [14]. The official order transferring a nurse to another job may not be appealed to the court [15].

Therefore, if the above-mentioned conditions are met, the refusal to comply with the employer's instructions constitutes a violation of the employee's obligations. In some circumstances, it can also be a serious violation, justifying an immediate termination of the employment pursuant to Article 52 of the Labour Code [16].

\section{Legal consequences for a nurse in the case of a refusal to transfer}

The employee has the right to maintain that transferring them temporarily to perform work other than that specified in the employment contract is not dictated by the legitimate needs of the employer or does not correspond to the employee's qualifications. In the event of a dispute between a nurse and an employer, however, there may be serious consequences for the employee.

The nurse's refusal to perform the newly entrusted work may be the basis for depriving an employee of their right to remuneration for the period of not performing work [17]. In addition, the refusal to take up the new duties by the abovementioned persons may be a justified reason for the termination of the employment contract pursuant to Article 52 of the Labour Code [16] (so-called disciplinary dismissal).

The entity that can settle disputes related to transferring a nurse or midwife to another job is the labour court [18]. In this case, the court will assess whether there were grounds to transfer the employee to another job and whether, therefore, the employee's refusal to take up the newly entrusted duties could justify their dismissal, pursuant to Article 52 of the Labour Code $[16,19]$. The court will assess the behaviour of an employee who has refused to take on the entrusted job in light of violating the obligation to carry out the supervisor's orders regarding work that is not contrary to the provisions of law or employment contract [20, 21].

In the Labour Code the legislator did not provide compensation for non-compliant referral of an employee to work pursuant to Article 42 Paragraph 4 of the Labour Code [2]. The employee might be able to seek compensation for damages on the general prin- ciples provided for in the Civil Code. The legal basis for the employer's liability for damages constitutes Article 471 of the Civil Code in connection with Article 300 of the Labour Code $[6,15,22]$.

\section{POSSIBILITY OF TRANSFERRING A NURSE EMPLOYED UNDER CIVIL LAW EMPLOYMENT TO A JOB OTHER THAN THE ONE PREVIOUSLY ARRANGED}

The civil law employment of nurses is not subject to the rigors of the labour law; therefore, the above remarks do not apply to them.

The answer to the question whether nurses employed under a civil law agreement, the so-called contract, may be delegated by the employer to perform other tasks, including the care of persons with suspected coronavirus infection, as a rule depends on the will of the parties.

In practice, the decisive factor will be the content of the already concluded contract, or new arrangements between the nurse (employee) and the employing entity (employer).

Due to the current legal status, the types and content of civil law employment contracts for nurses with healthcare entities are quite diverse in practice. Civil law contracts concluded for the purpose of employment may be both named and unnamed. To these contracts, the provisions on contracts in general, contained in the general part of civil law (Book I of the Civil Code), and the relevant provisions of the general part of the law of obligations (Book III of the Civil Code) apply.

There is much more freedom here in shaping the content of contracts. The parties concluding the contract may arrange a legal relationship at their discretion, as long as the content or purpose does not contradict the jurisdiction (nature of the relationship), the law, or the principles of social co-existence [23]. The violation of any of the criteria of contractual freedom listed in Article $353^{1}$ of the Civil Code [23] triggers a penalty of invalidity, which Article 58 of the Civil Code [24] applies to any activity contrary to the provisions of the Act.

As a rule, in the case in which a civil law contract strictly defines the scope of the duties between the nurse (employee) and the healthcare entity (employer), and the healthcare entity wants to entrust the nurse with other tasks, the nurse's consent for such a change is necessary. If a nurse refuses to perform the new duties, they retain the right to remuneration if they are ready to perform their current duties.

In the labour market there are also civil law contracts that provide for a general obligation to perform only generically defined services (e.g. nursing services). In this case, there are fewer arguments for the possibility of refusing to accept the new tasks falling 
within the so-called nursing services. Then it would be difficult to show that these nursing services do not include, for example, the care of persons with suspected coronavirus infection.

Another category of contracts that should be distinguished provides for the unilateral change of the scope of contractual services of a nurse (employee) by a healthcare entity (employer). In this case, as a rule, one should opt for the ineffectiveness of this type of regulation, i.e. the inability to unilaterally change the content of the contract. It will be different, however, if the contract stipulates precisely in which cases it will be possible for the healthcare entity (employer) to indicate a new, specific service instead of the basic one. As a rule, such a regulation is permissible. Then it can be a provision that allows the expansion of the scope of nursing or obstetric services by adding the care of people with suspected coronavirus infection.

In conclusion, if the civil law agreement allows the statement that the new duties of the nurse also include the care of persons with suspected coronavirus infection, the consequence of the non-performance thereof is the nurse's liability for damages on general principles. It is also possible that the contract provides for a contractual penalty, which is a significant facilitation for the employer, as they will not be obliged to prove the damage.

\section{ADMINISTRATIVE AND LEGAL PROCEDURE - REFERRING A NURSE TO WORK ON THE BASIS OF AN ADMINISTRATIVE DECISION}

Notwithstanding the above-mentioned possibilities of entrusting an employee with work pursuant to Article 42 Paragraph 4 of the Labour Code [2] and the possibility of taking care of persons with suspected coronavirus infection based on civil law contracts, the Act from December 5, 2008 on preventing and combating infections and infectious diseases in humans provides for specific legal regulations in the event of combating an epidemic.

\section{Rules for referral to work in combating an epidemic}

The voivode or the minister of health has the right to refer a nurse to work in combating an epidemic by way of an administrative decision [25, hereinafter: Infectious Diseases Act].

The administrative decision referred to above may be addressed to any person who is a member of the professional group of nurses and midwives, i.e. persons who have been granted the right to practice the profession of nursing and are in the register kept by the regional council competent for the place of occupation [26]. This means that the decision may be the basis for referring to work both nurses who have previously performed work in a healthcare entity under an employment contract or under a civil law contract, as well as nurses who have practiced the profession as part of professional practices [27, hereinafter referred to as the Healthcare Activity Act], and nurses who have not so far exercised the profession in healthcare entities, i.e.: 1) employed in entities obliged to finance healthcare services from public funds within the meaning of the Act from August 27, 2004 on healthcare services financed from public funds [28] or offices of those operating entities, under which the activities related to the preparation, organisation, or supervision of healthcare services are carried out; 2) employment in public administration bodies whose scope of activities includes supervision of health protection; 3) employment in nursing homes and employment as a nurse in a nursery or children's club, referred to in the Act from February 4, 2011 on the care of children under three years of age [29]; 4) exercising functions of choice in the self-government of nurses and midwives or performing work for the self-government; and 5) appointed to perform the union function outside the nurse's workplace, or to perform the function on the board of the trade union organisation [30].

The nurse is referred to work in combating the epidemic by way of a decision, i.e. an administrative decision is addressed to the individual nurse or midwife.

The decision to refer a nurse to work in combating an epidemic in the province in which the referral person has a place of stay or is employed, is issued by the competent voivode, and in the event of referral to work in the territory of another voivodship, the competent minister for health [31]. The referral decision to combat the epidemic is directed to the individual nurse and creates the obligation to work for up to three months in the indicated healthcare entity or other organisational unit.

The current employer is obliged to grant a person referred to combat an epidemic unpaid leave for a period specified in the decision of the voivode or the minister of health, which is included in the period of work on which the employee's rights at that workplace depend. In turn, the healthcare entity or organisational unit to which the nurse is referred establishes with them an employment relationship for the time of performing the job, for a period not longer than indicated in the decision [32]. In this way, a person referred to work on the basis of a decision of a voivode or the minister of health becomes an employee of the institution to which they were referred for a maximum of three months. However, the employment of nurses by the representatives of the facilities to which they were referred under civil law contracts constitutes a violation of the provisions. 
A nurse or midwife referred to work on the basis of a decision is entitled only to a basic salary in the amount not lower than $150 \%$ of the average basic salary provided for a given position in the workplace indicated in that decision or in another similar workplace, if there is no such position in the indicated workplace. The remuneration may not be lower than the remuneration that the person referred to work received in the month preceding the month in which the decision was sent [33]. In addition, they are entitled to a reimbursement of the costs of travel, accommodation, and meals, as according to the provisions on the amount due to employees of state entities for business travel throughout the country. The reimbursement of expenses for accommodation or meals is not granted if free lodging or meals are provided at the place of work [34].

The existing employment relationship with the nurse or midwife referred to work in combating the epidemic cannot be terminated, nor may the employment contract be terminated, unless there is a basis for terminating the employment contract without notice due to the employee's fault or in the event of a change or revocation of the decision. The provisions of Articles 63-67 of the Labour Code shall apply accordingly $[35,36]$.

\section{Exception to the rule - exclusion of people who cannot be referred to work in combating an epidemic in the administrative mode}

There is an exception to the general rule that a nurse, regardless of the legal form of practicing their profession, may be referred to work in fighting an epidemic, i.e. including the care of persons with suspected coronavirus infection [37]. An exception to the above rule is the prohibition of referring a nurse to a work that would put them at a risk of becoming infected while combating an epidemic, if at least one of the following circumstances applies to the person [38]:

- persons who are under 18 years of age or over 60;

- pregnant women;

- single parents bringing up a child up to 18 years of age;

- people raising a child up to 14 years old;

- persons raising a child with a disability certificate or a certificate of need for special education;

- persons with partial or total incapacity to work;

- if a child over 14 years of age is raised by two people with parental authority, only one of them may be referred to combat the epidemic;

- invalids and persons with chronic diseases;

- persons referred to in Article 2 of the Act from July 31, 1981 on the remuneration of persons in managerial positions [39], as well as deputies and senators of the Republic of Poland.
Thus, a nurse qualified to the above-mentioned group of people cannot be referred to work in combating an epidemic on the basis of an administrative decision of a voivode or a minister of health. However, if such a decision is issued despite this, it may be appealed to the minister of health due to being in the list of persons to whom this obligation does not apply.

\section{Sanction for failure to comply with an administrative decision not to take up employment}

The lack of compliance with the administrative decision to combat the epidemic is an offense for which a fine of PLN 20 to PLN 5000 is punishable [40]. In imposing the penalty, the offender's income, personal and family conditions, property relations, and earning potential are taken into account.

It should be noted that the imposition of the above-mentioned penalty is not a free decision of the voivode, if the nurse does not comply with the content of the issued decision, the voivode has the legal obligation to impose such a penalty.

\section{CONCLUSIONS}

The provisions of the Act from March 2, 2020 on special solutions related to the prevention, counteracting, and combating of COVID-19, other infectious diseases, and crisis situations caused by them have introduced specific measures to combat the epidemic, creating new challenges for the nursing environment.

A nurse employed on the basis of an employment agreement may be transferred to take care of persons with suspected coronavirus infection in accordance with the provisions of the labour law, i.e. provided that a total of four statutory conditions are met: 1) it must be justified by the needs of the employer, 2) it does not cause a reduction of the employee's remuneration, 3) it corresponds to the employee's qualifications, and 4) the performance of another job may not exceed three months in a calendar year [2].

At present, organisational changes carried out by the public healthcare entity in connection with the implementation of obligations arising from the prevention, counteracting, and combating of COVID-19 may be regarded as "justified employer's needs".

Under Article 229 Paragraph 1 Clause 2 of the Labour Code in relation to Article 10 Section 1 of the Infectious Diseases Act [11, 41] employers are currently relieved from their obligations, i.e. conducting preventive examinations.

Nurses with an employee status, who are transferred to perform tasks other than the ones specified in the employment contract, by way of an employer's official order issued in accordance with Article 42 Paragraph 4 of the Labour Code [2], are not subject to 
exclusion due to the care of a minor child, a chronically ill person, or due to age over 60 years.

However, according to the Labour Code, women will be subject to such exclusion during pregnancy or nursing a baby. In accordance with Article 176 Paragraph 1 of the Labour Code [42], pregnant women and women who are breastfeeding cannot perform onerous, dangerous, or harmful work that may have an adverse effect on their health, pregnancy, or breastfeeding. Detailed provisions are included in the Regulation of the Council of Ministers from April 3, 2017 on the list of onerous, dangerous, or harmful work in pregnant women and breast-feeding women, Journal of Laws (Dziennik Ustaw) from 2017 item 796 [43].

The possibility of obliging a nurse employed on the basis of a civil law contract to take care of persons with suspected coronavirus infection is decided by the parties by making a declaration of will in the contract.

A nurse, regardless of their current form of occupation, may be referred to work in combating an epidemic, including the care of persons with suspected coronavirus infection, through the administrative-legal mode, based on the decision of the voivode or the minister of health. Only nurses who belong to one of the groups subject to exclusion pursuant to Article 47 Section 3 of the Infectious Diseases Act [38] cannot be referred in this mode.

The obvious role of the public authorities and the management of the healthcare facilities to which nurses are transferred or referred to the work is to create safe working conditions to minimise threats to their health and life by proper staffing of workplaces and providing personal protective equipment, in particular masks and protective suits, gloves, and disinfectants.

\section{Disclosure}

The author declares no conflict of interest.

\section{References}

1. Article 10 Section 3 of the Act from March 2, 2020 on special solutions related to the prevention, counteracting and combating of COVID-19, other infectious diseases, and crisis situations caused by them; Journal of Laws (Dziennik Ustaw) from 2020 Item 374.

2. Article 42 Paragraph 4 of the Labour Code.

3. Judgement of the Supreme Court from August 8, 1979, I PR 55/79, OSNC 1980, No. 1-2, item 30].

4. Article 10 of the Crisis Act.

5. Article 6 of Civil Code.

6. Article 300 of Labour Code.

7. Judgement of the Supreme Court from May 8, 1997, I PKN 131/97, OSNP 1998/6, item 178.

8. Judgement of the Supreme Court from October 4, 2000, I PKN 61/00, Pr. Pracy 2001, No. 5, p. 33.

9. Judgment of the Administrative Court in Poznan from January 25, 2017, III AUa 560/16, LEX No. 2265714.

10. Judgement of the Administrative Court in Szczecin from June 20, 2017, III AUa 895/16, LEX No. 2338473.
11. Article 229 Paragraph 1 Item 2 of the Labour Code.

12. Article 12a Section 1 Item 1 of the COVID-19 Act.

13. Judgment of the Supreme Court from September 18, 2014, III PK 138/13, LEX No. 1504877.

14. Judgment of the Supreme Court from December, 72017 , II PK 323/16, LEX No. 2434447.

15. Judgment of the Supreme Court from July 25, 2003, I PK 269/02, Legalis. OSNP 2004, No. 16, item 280.

16. Article 52 of the Labour Code.

17. Judgment of the Supreme Court from March 29, 1978, I PR 20/78, PiZS 1979, No. 11, p. 73.

18. Judgment of the Supreme Court from August 18, 1976, I PR 103/76, OSP 1978, No. 3, item 44.

19. Judgment of the Supreme Court from September 26, 1978, I PRN 54/78, OSNC 1979, No. 3, item 60.

20. Article 100 Paragraph 1 of the Labour Code.

21. Judgment of the Supreme Court from November 18, 1999, I PKN 370/99, OSNAPiUS 2001, No. 7, item 225.

22. Article 471 of the Civil Code.

23. Article 3531 of the Civil Code.

24. Article 58 of the Civil Code.

25. Article 47 of the Act from December 5, 2008 on preventing and combating infections and infectious diseases in humans, consolidated text of the Journal of Laws (Dziennik Ustaw) from 2019 item 1239.

26. Article 5 of the Act from July 1, 2011 on the self-government of nurses and midwives, Journal of Laws (Dziennik Ustaw) from 2018 item 916.

27. Article 19 of the Act from April 15, 2011 on healthcare activities, consolidated text of the Journal of Laws (Dziennik Ustaw) from 2020 item 2190.

28. Act from August 27, 2004 on healthcare services financed from public funds Journal of Laws (Dziennik Ustaw) from 2019, item 1373, as amended.

29. Act from February 4, 2011 on the care of children under three years of age Journal of Laws (Dziennik Ustaw) from 2020, item 326.

30. Article 4 Section 2 of the Nursing Act.

31. Article 42 Paragraph 2 of Infectious Diseases Act.

32. Article 47 Paragraphs 7-9 of the Infectious Diseases Act.

33. Article 42 Section 10 of the Infectious Diseases Act.

34. Article 42 Section 11 of the Infectious Diseases Act.

35. Articles 63-67 of the Labour Code.

36. Article 42 Section 13 of the Infectious Diseases Act.

37. Article 42 Section 1 of the Infectious Diseases Act.

38. Article 47 Section 3 of the Infectious Diseases Act.

39. Article 2 of the Act from July 31, 1981 on the remuneration of persons in managerial positions; Journal of Laws (Dziennik Ustaw) from 2019, item 152.

40. Articles 53 and 54 of the Act on preventing and combating infectious diseases in humans in connection with Article 24 Paragraph 1 and 3.

41. Article 10 Section 1 of the Infectious Diseases Act.

42. Article 176 Paragraph 1 of the Labour Code.

43. Regulation of the Council of Ministers from April 3, 2017 on the list of onerous, dangerous, or harmful work in pregnant women and breast-feeding women, Journal of Laws (Dziennik Ustaw) from 2017 item 796. 